Faculty Scholarship

2009

\title{
Legal Research Assessment
}

Simon Canick

Mitchell Hamline School of Law, simon.canick@mitchellhamline.edu

Publication Information

28 Legal Reference Services Quarterly 201 (2009)

\section{Repository Citation}

Canick, Simon, "Legal Research Assessment" (2009). Faculty Scholarship. Paper 122.

http://open.mitchellhamline.edu/facsch/122

This Article is brought to you for free and open access by Mitchell Hamline Open Access. It has been accepted for inclusion in Faculty Scholarship by an authorized administrator of Mitchell Hamline Open Access. For more information, please contact sean.felhofer@mitchellhamline.edu.

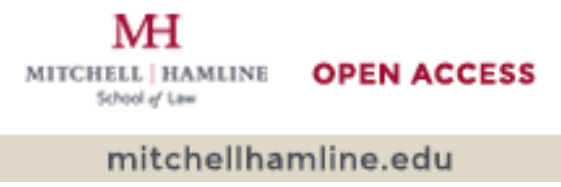




\title{
Legal Research Assessment
}

\begin{abstract}
Legal research instructors seek to provide their students with a working knowledge of important research tools, strategies with which to develop a rational research plan, and the skill to conduct research efficiently, among other things. A well-conceived legal research class may utilize short-answer assignments, quizzes, and scavenger hunt exercises as a means to establish a baseline of knowledge with critical sources; a series of research problems, with grading based upon students' ability to describe a coherent and logical progression; and a pathfinder or process-oriented final exam, all depending on the instructor's goals. Ultimately, the variety of available assessment tools suggests room for creativity and the existence of many appropriate alternatives. As long as instructors use a multifaceted approach, selecting assessment tools to suit course objectives, students will be engaged in the process and will become stronger, more confident legal researchers.
\end{abstract}

\section{Keywords}

assessment, legal research, examinations, instruction

\author{
Disciplines \\ Legal Education | Legal Writing and Research
}




\title{
Legal Research Assessment
}

\author{
SIMON CANICK \\ Warren E. Burger Law Library, William Mitchell College of Law, \\ St. Paul, Minnesota, USA
}

\begin{abstract}
Legal research instructors seek to provide their students with a working knowledge of important research tools, strategies with which to develop a rational research plan, and the skill to conduct research efficiently, among other things. A well-conceived legal research class may utilize short-answer assignments, quizzes, and scavenger bunt exercises as a means to establish a baseline of knowledge with critical sources; a series of research problems, with grading based upon students' ability to describe a coherent and logical progression; and a pathfinder or process-oriented final exam, all depending on the instructor's goals. Ultimately, the variety of available assessment tools suggests room for creativity and the existence of many appropriate alternatives. As long as instructors use a multifaceted approach, selecting assessment tools to suit course objectives, students will be engaged in the process and will become stronger, more confident legal researchers.
\end{abstract}

KEYWORDS assessment, legal research, examinations, instruction

\section{INTRODUCTION}

At the rate law librarians are now teaching research courses in law schools nationwide, it is hard to believe that a classroom role took so many years to cement. Indeed, librarians' formal teaching loads have reached historic highs.

Association of Legal Writing Directors/Legal Writing Institute figures show that in 2002, librarians taught the research component of first-year courses at seventy-seven institutions (forty solo and thirty-seven as coteachers). ${ }^{1}$ By 2008, that number had increased to one hundred eighteen

Address correspondence to Simon Canick, Warren E. Burger Law Library, William Mitchell College of Law, 871 Summit Avenue, St. Paul, MN 55101-3030. E-mail: simon.canick@ wmitchell.edu 
institutions (fifty-two solo and sixty-six as co-teachers), an increase of fifty-three percent. And the number of advanced courses taught by librarians has risen by eighty-nine percent, from sixty-four courses in 2000 to 121 in $2008 .^{2}$

Several reasons justify the surge. For one, doctrinal faculty rarely showed interest in teaching research, ${ }^{3}$ so at most law schools, teaching of the first-year legal research and writing classes was farmed out to adjuncts or professional legal research and writing teachers. Practitioner-teachers, many of whom lack research skills themselves, unsurprisingly steer their courses away from legal research. ${ }^{4}$

More importantly, over the past fifteen years, a call has emerged for legal education to become more practical and skills based. In 1992, the influential MacCrate Report produced an outline of the fundamental lawyering skills to promote at law schools, including problem solving, legal research, factual investigation, counseling, negotiation, and litigation procedures. ${ }^{5}$ In 2007, the Carnegie Report issued a sharp critique of legal education, finding that most law schools demonstrate only:
casual attention ... to teaching students how to use legal thinking in the complexity of actual law practice .... The result is to prolong and rein- force the habits of thinking like a student rather than an apprentice prac- titioner, thus conveying the impression that lawyers are more like com- petitive scholars than attorneys engaged with the problems of clients. ${ }^{6}$

The legal academy has begun to recognize its obligation to train students who act like lawyers from the moment of graduation. But perhaps this realization comes from a complaining bar, rather than self-awareness. The legal profession is demanding a change, arguing that even traditional doctrinal courses need practical components. Further, voices inside and out of the American Bar Association (ABA) have called for a formal tie of a skills-based curriculum to accreditation. ${ }^{7}$

Meanwhile, despite the relative practicality of legal research instruction, law firms remain disappointed with the research skills of recent graduates. ${ }^{8}$ In part, this dissatisfaction can be explained by the fact that most students receive significant training only during the fall semester of their first year in law school - most assuredly not the point of their need. Advanced legal research (ALR) classes reach only a small fraction of law students.?

In this environment, administrators listen carefully to proposals from librarians who seek a more active role in teaching research. The challenge for librarian-teachers is to develop in their students a sound and confident approach to research, so that when they enter practice they can find the law quickly and efficiently. In ten more years, librarians may dominate the teaching of legal research in law schools, but we will have failed if our students still cannot demonstrate effective research skills to law firms and clients. 
The goal of this essay is to suggest a method of ensuring good outcomes in legal research training. It begins with a list of skills that students need and follows with a discussion of the means to "test" students' achievement of those skills. It concludes with a proposal for a multifaceted research curriculum.

\title{
GOALS OF LEGAL RESEARCH INSTRUCTION AND ASSESSMENT
}

\begin{abstract}
In order to conduct legal research effectively, a lawyer should have a working knowledge of the nature of legal rules and legal institutions, the fundamental tools of legal research, and the process of devising and implementing a coherent and effective research design. ${ }^{10}$
\end{abstract}

The MacCrate report's statement of knowledge necessary for lawyers to conduct research includes three fundamentally different types of skills, and different skills require diverse teaching and assessment techniques. For example, students striving for a working knowledge of the nature of legal rules and institutions should probably complete some background reading, listen to an illuminating lecture, and then engage in dialogue to answer questions that arise. On the other hand, developing facility with one of the tools of legal research, say LexisNexis, may still require some background reading and lecture, but most important is giving students an opportunity to practice-perhaps with choosing the best database or constructing an effective search.

The purpose of assessment in legal research is to "evaluate a student's learning - what the student knows and what the student can do with the new knowledge and skills." 11 We aim to determine whether the student is "getting it" in these lectures, readings, and practice exercises, such that we can build on what we have covered and move on to more sophisticated research techniques.

To determine whether students have a working knowledge of the nature of legal rules and institutions, the teacher may use an assessment tool like Socratic dialogue or give the class a short-answer quiz. Teaching effective use of LexisNexis, on the other hand, likely involves process-oriented assessment, like research logs to accompany research exercises or firsthand observation. In other words, an appropriate curriculum will include assessment tools that are chosen to complement the skill in question.

Keeping in mind that legal research instructors aim for a wide variety of outcomes (e.g., developing and executing a rational research plan, conducting efficient research, knowing when to stop, etc.), this article will review some of the most frequently used assessment tools and a few you might not have considered. When designing your own course, you might appropriately "pick and choose" from these tools, depending on the subject matter at hand, the particular dynamic in the classroom, and 
the learning objective you are seeking. There is nothing inconsistent or inappropriate about using a variety of approaches within a single class; indeed, as explained below, it is desirable to do so.

Insofar as legal research courses are practice based and use assessment tools that are more precise than the blunt, end-of-semester, all-or-nothing final exam, they are consistent with current thought on best practices in legal education. In the 2007 report, Best Practices for Legal Education: A Vision and a Road Map, Roy Stuckey described assessment in law schools as "inadequate," "flawed," and "abominable," but at least partially exempted legal writing and research courses from his critique. ${ }^{12}$ It is worth noting, however, that legal research instruction has evolved significantly over the years. ${ }^{13}$ (Indeed, it is the perception that doctrinal law courses have failed to progress since the time of Langdell that so frustrates contemporary commentators.) $)^{14}$

In a superb article published in 2003, Paul Callister traced the history of the most significant pedagogical split in the hundred years or so of formal legal research instruction. ${ }^{15}$ In 1988, Christopher Wren and Jill Robinson Wren attacked "bibliographic" legal research instruction, arguing that "students in legal research courses are given descriptions of law books without adequate instruction about how or when to use the books. Bibliographic information requires a context to make it meaningful for a legal researcher, and the necessary context is how someone actually does legal research."16 Bob Berring and Kathleen Vanden Heuvel responded the next year, ${ }^{17}$ provoking a second article by the Wrens, ${ }^{18}$ which in turn compelled a last word from Berring and Vanden Heuvel. ${ }^{19}$ The back-and-forth left its mark, and to this day librarians debate how best to design courses with process-based, experiential principles in mind. ${ }^{20}$

As time went on, bibliographic instruction began to sound more oldfashioned. The caricature of this model is a librarian at the front of the classroom with a cart of books. "This is called the Code of Federal Regulations. It's where you can find rules and regulations of administrative agencies as of a certain date. Notice how the color of the cover changes each year. You'll find it in the Federal Room in the library. I'll pass some copies around." Students fall into a trance-like state out of sheer boredom.

The bibliographic approach does not teach students why legal research is necessary or how it ultimately will be used to solve legal problems, and it rarely gives students a framework upon which to build their knowledge. The amount of information taught in a bibliographic-based course is often overwhelming and detailed and is quickly forgotten because it is learned out of context and is seldom applied. ${ }^{21}$

The assumed methods of assessment for this model include scavenger hunt exercises to find predetermined, correct answers, and an objective, multiple-choice final exam. ${ }^{22}$ Teachers determine which students have best 
memorized information about sources-what is in them and how to use them.

Conversely, process-based research instruction might emphasize students' development of a research process related to an ill-defined set of facts. Class time is devoted to students' attempts to implement their plans by using the resources they deem appropriate. Assessment might derive from post-exercise debriefings, from subjective evaluation by the instructor based on firsthand observation, or from students' narrative descriptions of research processes undertaken to solve take-home research assignments.

I mention these concepts because they play into our perceptions of the assessment tools described in the next sections of this essay. My contention is that there is good and bad in both approaches-a thoughtful variety of tactics might be the best solution of all.

\section{A NOTE ABOUT TIMING}

As noted earlier, librarian participation in first-year research and writing programs has increased dramatically in recent years. In describing their pursuit of formal teaching responsibilities for librarians in the first-year program at the University of Richmond School of Law, Joyce Janto and Lucinda Harrison-Cox wrote that, "[a]s librarians, we felt uniquely qualified to teach legal research and appreciated this opportunity to show how legal research should be taught, because we all felt that the instruction we had received in law school was inadequate." 23 But teaching first-year law students (1Ls) is not easy, and factors exist that can lead to disappointing outcomes. First, librarians are often invited as guest lecturers, rather than being designated as co-teachers, or collaborating with named instructors in meaningful ways. Oftentimes, research lectures are scheduled outside of regular class time, irritating students. The primary instructor may make research lectures voluntary or may fail to attend the sessions herself, sending a signal to her students that the content lacks importance. ${ }^{24}$

Second, it is axiomatic that legal research instruction is most successful when it comes at the point of need. First-year students are struggling to manage their doctrinal courses and get good grades which can unlock the doors to law review or a summer position with a big law firm. ${ }^{25}$ In this regard, research and writing courses are at a profound disadvantage. "[Law] schools usually do not give significant academic weight to courses in legal writing, lawyering, or clinical education. This tends to undercut, as does the competitive climate, the seriousness of the assessment that students receive in these courses." ${ }^{26}$ Unlike 1Ls, upper-class students have self-selected into graded, elective research courses. Most of them have already experienced summer employment in a legal setting, and understand better why research skills are important. 
Third, teaching in the first-year program often means working with hundreds of students. Even if you have several librarians to assist, you probably will not have time to offer a significant level of feedback. That means relying on objective assessment tools, like short-answer questions, that are easier to grade. ${ }^{27}$

ALR and similar electives solve some of these problems because motivated students self-select into the courses, and limited enrollments make it feasible for instructors to create process-based exercises with meaningful feedback.

\section{LEGAL RESEARCH ASSESSMENT TOOLS}

Whatever the venue, teachers must approach legal research like any other class; intentionally creating coordinated goals, syllabi, readings, and assignments that are carefully designed to convey information and challenge students. Assessment is the last piece, and instructors must choose assessment tools to further course goals.

\section{Objective Homework Assignments and Quizzes}

Whether in the first year or an advanced course, one goal is probably to teach students about a group of important sources-what is in them, where you find them, how you use them, etc. Objective assignments, which may take the form of multiple choice, true/false, or short-answer questions, force students to review their notes and memorize important information that can be built upon with further practice. ${ }^{28}$ They give instructors a way to evaluate students, while saving a huge amount of time in grading. ${ }^{29}$ Students are also "more likely to accept the results and work to improve performance. Students sometimes dismiss poor results on essay examinations as the result of the professor's arbitrary stylistic preferences." 30

Many librarians reject "scavenger hunt" exercises on the grounds that they bear no resemblance to real-life research problems, ${ }^{31}$ ignore connections between sources, and artificially limit students to one type of material at a time. ${ }^{32}$

When developing materials for the course, we firmly rejected the old "treasure hunt" methodology, which we all had suffered through when learning legal research ourselves. We were unanimous in our agreement that treasure hunts are not only time consuming and frustrating, but also of limited educational value. Because each source is presented in a vacuum, relationships between different types of material are never made clear to students. The only point these exercises drive home to novice 
researchers is an unintended and erroneous one-that a legal question has only one right answer. ${ }^{33}$

Basing an entire class around short-answer exercises would not make sense, of course, because you would ignore students' choices surrounding the research process. ${ }^{34}$ But scavenger hunts and other short-answer exercises are not without merit and can be useful as part of a comprehensive program.

\section{Research Exercises}

When several pieces of knowledge or several skills are evaluated simultaneously, a challenging assessment forces students to learn in more complex and effective ways than if each were assessed separately. This is, in large part, why simulation assignments-assignments that place students in the role of a practicing attorney-are superior to traditional "quiz" assignments. Asking students to solve a legal problem through research is more challenging than asking them to provide answers for a series of sterile research questions. ${ }^{35}$

Unlike quizzes and short-answer exercises, significant research exercises are challenging because they test several skills simultaneously. For example, research related to a factual scenario ${ }^{36}$ may involve selecting appropriate secondary sources, choosing the format of selected material, deciding to change course upon hitting a roadblock, demonstrating how to use a good case from one jurisdiction to find similar cases in another, and considering whether you are safe to stop, among many other things. Multifaceted problems naturally test students' ability to form a coherent plan. They also allow for creative problem solving and depending on the scenarios involved, may give students a personal connection to the subject matter of the exercise.

Many ALR courses use weekly assignments for this purpose. ${ }^{37}$ Students submit responses in the form of "research logs." This diary is designed to tell the instructor, usually in narrative form, what the student did at each step in the process and why. Research logs force students to compose a research plan and (attempt to) follow it through to completion, improvising when necessary to move the process along. ${ }^{38}$ They also offer students an opportunity for self-reflection (e.g., "in retrospect, I should have given up at this point and moved on to another source") ${ }^{39}$ and enable teachers to offer quick feedback. ${ }^{40}$ Instructors may write personal comments in the margin, e.g., "you'd have gotten a better result set by using a field restriction," respond to humorous remarks, and otherwise make a constructive, personal connection with the student. Noticing that several students have made similar errors prompts teachers to cover the right ground when reviewing assignments with the entire class. 
Despite some obvious benefits, research logs are probably inadequate if they serve as an instructor's sole method of assessment. That's because the student's narrative does not necessarily describe the process you would see if you watched it yourself. As Brian Huddleston asked, "[w]ould the winner of a piano competition be as renowned if the contestants merely described in an essay how they would style and perform a particular piece?" 41 And of course, students probably misrepresent their research process, leaving out some of their less productive tangents. ${ }^{42}$

The hardest part about using research logs to collect information is the amount of time that it takes to review and provide meaningful feedback. It can take at least thirty minutes to review one research log, meaning that for a class of twenty, you need to find ten hours of review time. ${ }^{43}$ As a weekly exercise, this is difficult to sustain. In 2002, Kristin Gerdy proposed the use of group feedback memos. This promising variation employs a memorandum from the teacher to all students in the class, and features a description of recurring problems. ${ }^{44}$ Gerdy writes, "[s]uch a group feedback memo is useful not only for individuals who had particular problems but also for students who did not have the problems because it identifies areas where they were successful and helps them avoid the problems should they arise in the future." 45

\section{Observation \& Dialogue}

In a perfect world, we could see a student's research process, evaluate that process, and provide quick feedback. Using narrative research logs, prepared by students, is a good but imperfect approach. Fortunately, there are other methods to learn how students see the problem before them and gauge their thought process as they seek to solve it.

One such approach is to engage in Socratic dialogue with students. ${ }^{46}$ It is likely that librarians teaching skills courses, such as legal research, hesitate to embrace the techniques of doctrinal law professors, but there can be significant benefits. Asking students to describe their handling of in-class exercises, for example, and then following up with probing questions will help you to develop a list of the kinds of concepts your students do not understand. And knowing they may be called on will encourage a higher level of engagement and attention throughout your classes.

If you want to avoid this route, consider inviting students to try research problems with the computer attached to the classroom projector. ${ }^{47}$ So much of teaching legal research involves electronic resources that it is easy to find opportunities for students to demonstrate short projects from start to finish. If they get stuck, others can shout out suggestions.

Better yet, take advantage of technology to capture the entire electronic research process. Teach your students how to use screencasting software like 
Captivate, ${ }^{48}$ Camtasia, ${ }^{49}$ or a free, open-source alternative like CamStudio, ${ }^{50}$ and have them use it to solve a research problem. Students should include audio commentary to add context—e.g., "I'm starting with a Westlaw natural language search because ...." This enables the instructor to view an actual research process, while avoiding the pressure students may feel while performing in front of a class or otherwise being watched.

\section{Peer Assessment}

Students can more fully participate in the educational process by critiquing the work of their peers. But unlike undergraduate institutions, where a tradition of formal peer assessment and grading has developed, there is no similar model in law schools. In part, this is because the case method dominates, but even in skills courses we hesitate to use peer assessment because students are not comfortable being graded by their peers. ${ }^{51}$ In particular, students believe peers are not competent to assess their work. ${ }^{52}$

Students can, however, gain significant benefits from a program of peer feedback. "By peer feedback, we mean a communication process through which learners enter into dialogues related to performance and standards." ${ }^{53}$ The practice entails establishing the criteria for assessment and rating peers in terms of those criteria. ${ }^{54}$ Setting feedback standards requires agreement between students and teacher during a class dialog.

Once we begin asking questions about how assessors arrive at marks, we are involved in a process of defining learning outcomes and the criteria for assessing those outcomes. This intellectual engagement with outcomes, criteria, and standards is at the heart of student involvement in assessment and can lead to great clarity about the nature of high-quality performance. $^{55}$

Critiquing peers gives student reviewers insight into what it takes to achieve success themselves. That understanding stimulates valuable self-assessment (e.g., "Am I achieving these standards myself?"; "How has my own process fallen short?") $)^{56}$

The process also teaches students how to provide constructive feedback to colleagues and friends who they might ordinarily find difficult to criticize because of personal connections. And the reviewers' knowledge that roles may reverse (and they will face criticism later) lends the evaluation process greater seriousness.

Legal research instructors might want to establish a peer feedback regime as a way to engage students. And as teachers know from experience, the process of offering careful critiques stimulates further learning by demonstrating limitations in one's own understanding. ${ }^{57}$ 
To some extent, legal research teachers already take advantage of peer feedback during the regular give-and-take of class discussions. During lectures, one might introduce a problem and then ask a student, "What would you try first to solve this?" Rather than critiquing the response, the instructor could give others in the class an opportunity to comment. These explanations are chances for students to practice articulating their research processes-a skill they are likely to need in practice.

Another obvious application is to institute peer feedback into processoriented or longer term projects. As described earlier, many instructors use research logs as assessment tools for assignments. Rather than providing direct feedback, teachers could incorporate an intermediate feedback step, in which each student is assigned the task of critiquing the process employed by one of his or her peers. Student authors would be required to utilize feedback received in producing a final draft the next week, while the instructor could rate the quality of reviewers' comments.

Similarly, instructors might assign reviewers to critique preliminary drafts of final assignments, such as pathfinders. Both students in each designated pair would benefit - the author from the substantive observations given, and the reviewer by absorbing and understanding types of resources the author had selected.

\section{END OF SEMESTER ASSESSMENT}

\section{Pathfinder}

Since I began teaching ALR, I have required students to prepare pathfinders for their final project. ${ }^{58}$ The idea is that students choose a subject of interest and develop a pathfinder (sometimes called "research guide" or "annotated bibliography") that would help another researcher starting out in that topic. Students bring to bear all of the skills they learned during the course while building the guide. A brief, in-class presentation is the final component.

Other instructors reject the pathfinder:

The final component of the Advanced Legal Research course originally involved the use of a pathfinder. This tool ... is quite common among the advanced legal research courses. This component, however, did not work well in the course because development of the pathfinder is not an exercise with direct practical value. Its most significant weakness is that it fails to integrate problem-solving skills with the research process. ${ }^{59}$

While I disagree with the contention that pathfinders lack practical value, I accept the general point. Many research instructors pursue a practical curriculum, designed to give students the ability to handle all kinds of research problems with confidence and skill. The pathfinder project serves this purpose only indirectly. 
To be fair, preparing an excellent pathfinder can be fun and requires a high degree of judgment.

\begin{abstract}
We tell them not to be comprehensive. We do not want to see every case or journal article; we only want to see the ones that are significant. This is because we want them to practice using their judgment, not just their ability to collect resources. When they are practicing law, they will have to make research choices based on cost and deadlines. The pathfinder gives them an opportunity to develop the intuition they will need when they are lawyers. ${ }^{60}$
\end{abstract}

Furthermore, as Berring and Vanden Heuvel argued, the assignment may effectively bridge the gap between "conceptual understanding of the tools and working through of research questions that engenders excellent research skills." $" 1$

Still, juxtaposed against other assignments (e.g., research projects with assessment focused on the process), the pathfinder seems overly bibliographic and out of place. It belongs, perhaps, as one component but not as the culmination of the course.

\title{
Examinations
}

Exams are an obvious end-of-term assessment tool, but of course teachers can use them at any point during the semester. And although we consider exams as a separate assessment category, in reality they simply give teachers a framework in which to implement their preferred assessment choices. For example, objective questions (generally multiple choice, short answer, true or false, etc.) enable professors to establish a baseline of knowledge that they feel students should commit to memory. They are easy to grade, ${ }^{62}$ and students are "likely to spend more time studying and learning the material." 63 However, objective exams do not prove that students can use sources effectively, a fact that frustrates some commentators. ${ }^{64}$ Judith Rosenbaum, for example, wrote that:

While it certainly is true that knowledge acquisition is a necessary foundation for learning, because raw facts have to be absorbed, and often memorized, before higher forms of cognitive activity can take place, the essence of legal research is a search for understanding in which finding and thinking continually cross-fertilize each other and these mental processes cannot be emulated by an objective test. ${ }^{65}$

Douglas Miller states the counter-argument:

The education theorists who conclude that not every skill can be tested in three hours do not advocate the abolition of examinations: rather, they 
suggest that in-class examinations be used with other kinds of projects. Thus, if we conclude that there are skills taught in our courses that cannot be tested in three hours, it does not necessarily follow that examinations are useless for us, for the simple reason that we might use in-class examinations in conjunction with other kinds of assignments. ${ }^{66}$

One might add to Miller's point that just because one type of exam lacks practicality, that does not mean that we cannot conceive of a different kind of exam, one that focuses on process. ${ }^{67}$

A final examination based on firsthand observation makes more sense. One might structure it by scheduling appointments with individual students sometime during exam period. The time allotted could be used to elicit responses to questions about research processes (an oral exam) and to follow the student as he/she attempts to research an issue. Although extremely time consuming, with this method, the instructor may gain a better understanding of the student's research and reasoning skills.

\title{
RECOMMENDATIONS AND CONCLUSION
}

\begin{abstract}
We owe it to our students to try to be excellent teachers who skillfully employ a wide range of teaching methods. While poor instructional techniques may not particularly affect the very best students, the average and below average students depend on the quality and effectiveness of our instruction to succeed in law school, on the bar exam, and in practice. Law teachers should expertly employ a wide variety of teaching methods. Unfortunately, many of us do not. ${ }^{68}$
\end{abstract}

Legal research instructors seek to provide their students a working knowledge of important research tools, strategies with which to develop a rational research plan, and the skill to conduct research efficiently, among other things. Given the range of desired outcomes, it would be difficult to argue for the use of a single assessment tool. ${ }^{69}$ "Inherent in the quest for variety is the recognition that some assessment measures are more appropriate for some subjects or skills than they are for others." 70

A well-conceived legal research class may utilize short-answer assignments, quizzes, and scavenger hunt exercises as a means to establish a baseline of knowledge with critical sources. To follow it, teachers are advised to employ a series of research problems, with grading based upon students' ability to describe a coherent and logical progression. The problems' "answers" are less important than the selection of sources, reasonable use of those sources, and adherence to a plan. The assessment tool for such exercises might be some combination of research logs, Socratic dialogue, 
in-class presentations, or student-prepared Captivate/Camtasia/CamStudio screencasts. $^{71}$

As a final project, a pathfinder, however practical you might make it, is not sufficiently process oriented to stand on its own. If we believe that the most essential skill that teachers can impart is the ability to handle confidently and accurately research projects on unfamiliar subjects, then you should consider a process-oriented exam or another research project instead of (or in addition to) the pathfinder.

Using multiple assessment tools benefits your class whether you teach 1Ls or ALR. The rationales for variety-e.g., that different students learn in different ways, and that assessment should be tailored to the competencies being developed-are the same for both groups. In any legal research course, our objective is to teach multiple skills, which may include creating a research plan and choosing a source to start off, memorizing the official sources of legal materials (and where/how to find them), evaluating the benefits and drawbacks of indexes and full text searches, knowing when print-based research can still help, researching with a time pressure, selecting the most appropriate databases on Lexis or Westlaw, using natural language or terms and connectors, and assessing free Web sites, among hundreds of others. Some skills, like learning the difference between the Statutes at Large and the United States Code, are well suited for objective assessment tools like quizzes; others, like deciding the best place to start researching a complex issue, can best be evaluated with tools like research logs or direct observation. The administrative burden of teaching large first-year classes may make research exercises less practical, but leaving them out entirely would be a disservice to students.

Ultimately, the variety of available assessment tools suggests that there is room for creativity and that there are many appropriate alternatives. ${ }^{72}$ So long as instructors use a multifaceted approach, selecting assessment tools to suit their course objectives, students will be engaged in the process and will become stronger, more confident legal researchers.

\section{NOTES}

1. See Association of Legal Writing Directors/Legal Writing Institute, 2002 Survey Results, available at http://www.alwd.org/surveys/2002.html.

2. See Association of Legal Writing Directors/Legal Writing Institute, 200o Survey Results, available at http://www.alwd.org/surveys/2000.html. See also Ann Hemmens, Advanced Legal Research Courses: A Survey of ABA-Accredited Law Schools, 94 L. Lib. J. 209, 220 (2002) (finding a 700\% increase in the number of law schools offering ALR classes between 1983 and 2000).

3. Cf. Maureen Fitzgerald, What's Wrong with Legal Research and Writing? Problems and Solutions, 88 L. Lib. J. 247, 252 (1996) (noting that although "most law professors recognize the importance of research and writing, they seem unable as a group to find room for it in the curriculum.")

4. See id. at 271 .

5. ABA, Section of Legal Education and Admissions to the Bar, Legal Education and Professional Development: An Educational Continuum: Report of the Task Force on Law Schools and the Profession: 
Narrowing the Gap, Statement of Fundamental Lawyering Skills and Professional Values (1992) [hereinafter MacCrate Report].

6. William M. Sullivan et al., Educating Lawyers: Preparation For The Profession of Law 188 (Jossey-Bass/Wiley 2007) [hereinafter Carnegie Report]. The failure of law schools in this regard appears to be unique in professional education.

With some important exceptions, the underdeveloped area of legal pedagogy is clinical training, which typically is not a required part of the curriculum and is taught by instructors who are themselves not regular members of the faculty. Compared with the centrality of supervised practice, with mentoring and feedback, in the education of physicians and nurses or the importance of supervised practice in the preparation of teachers or social workers, the relative marginality of clinical training in law schools is striking.

Id. at 24

7. See MacCrate Report, supra n. 5, at 267 (concluding that "the statement should be an essential reference in the accreditation process"); Roy Stuckey et al., Best Practices for Legal Education: A Vision and a Road Map 17 (Clinical Legal Education Association 2007) (arguing that "[w]ithout clearer guidance from the accrediation [sic] standards and without any significant internal or external motivators to change the status quo, law schools have been slow to consider the implications of the ABA's mandate to prepare students for effective and responsible participation in the legal profession.")

8. See Joan S. Howland \& Nancy J. Lewis, Effectiveness of Law School Legal Research Training Programs, 40 J. Leg. Educ. 381 (1990). See also Paul D. Callister, Beyond Training: Law Librarianship's Quest for the Pedagogy of Legal Research Education, 95 L. Lib. J. 7, 9-11 (2003).

9. Librarians at many law schools have attempted to supplement formal course offerings with brown bag sessions, optional lectures, and "bridge the gap" programs specifically designed to assist summer associates and graduating students.

10. MacCrate Report, supra n. 5, at 157. Specifically, MacCrate advocates an understanding of: "various sources of legal rules and the processes by which these rules are made," sources providing "controlling principles for resolution of various kinds of issues ...," and "[t]he variety of legal remedies available in any given situation." Id . at 157-158. With respect to fundamental research tools, lawyers "should be generally familiar with the nature of the tool, its likely location in a law library, and the ways in which the tool is used." Id. at 159. Last, lawyers should understand how to formulate issues for research, identify "the full range of search strategies that could be used to research the issues ...," evaluate the search alternatives before settling on a "research design," and implement that design. Id. at 160-162.

11. Kristin Gerdy, Teacher, Coach, Cheerleader, and Judge: Promoting Learning Through LearnerCentered Assessment, 94 L. Lib. J. 59, 69 (2002); Stuckey, supra n. 7, at 236 (stating that the "primary reason to administer assessments is to find out whether our students are learning what we want them to learn.")

12. Stuckey, supra n. 7, at 238-239. "In sum, except perhaps in legal writing and research courses, the current assessment practices used by most law teachers are abominable." Id. at 239.

13. See generally Joyce M. Janto \& Lucinda D. Harrison-Cox, Teaching Legal Research: Past and Present, 84 L. Lib. J. 281 (1992)

14. See e.g. Stuckey, supra n. 7, at 236-238 (concluding that "the end-of-the semester essay exam is neither valid, nor realizable, nor fair."

15. See generally Callister, supra $\mathrm{n} .8$.

16. Christopher G. Wren \& Jill R. Wren, The Teaching of Legal Research, 80 L. Lib. J. 7, 10 (1988)

17. Robert C. Berring \& Kathleen Vanden Heuvel, Legal Research: Should Students Learn It or Wing It? 81 L. Lib. J. 431 (1989).

18. Christopher G. Wren \& Jill R. Wren, Reviving Legal Research: A Reply to Berring and Vanden Heuvel, 82 L. Lib. J. 463 (1990).

19. Robert C. Berring \& Kathleen Vanden Heuvel, Legal Research: A Final Response, 82 L. Lib. J. 495 (1990).

20. Berring recently remarked that "[a]lmost 20 years later one might wonder what the fuss was all about." Robert C. (Bob) Berring Jr., Twenty Years On: The Debate Over Legal Research Instruction, 17 Persps. Teaching Leg. Research \& Writing 1, 3 (2008). Available at http://west.thomson.com/pdf/ perspec/2008-Fall/2008-Fall-1.pdf. 
21. Fitzgerald, supra n. 3, at 255 .

22. See e.g. Douglas Miller, Using Examinations in First-Year Legal Research, Writing, and Reasoning Courses, 3 Leg. Writing 217 (1997). I hasten to add that I have oversimplified the concepts here in order to set an easy distinction. I am not trying to belittle the bibliographic approach generally or the use of examinations specifically. On the contrary, I find many of Mr. Miller's arguments persuasive.

23. Janto \& Harrison-Cox, supra n. 13, at 289.

24. Baylor Law School has handled this problem by untangling research and writing. In this system, students take a quarter-long, separately graded research class. See Matthew C. Cordon, Beyond Mere Competency: Advanced Legal Research in a Practice-Oriented Curriculum, 55 Baylor L. Rev. 1, 8 (2003). Similarly, Kory Staheli argues that making legal research into a separately graded course "provide[s] needed motivation and incentive for students to learn the material and to master necessary skills." Kory D. Staheli, Motivating Law Students to Develop Competent Legal Research Skills: Combating the Negative Findings of the Howland and Lewis Survey, 14 Legal Ref. Servs. Q. no. 1-2, at 195, 200-201 (1994).

25. See Carnegie Report, supra n. 6, at 173.

26. $I d$.

27. But see id. at 290 ("We stress that the students are being taught research techniques to insure basic competence, and that the students are themselves responsible for building upon this framework during their three years in law school.")

28. See Greg Sergienko, New Modes of Assessment, 38 S.D. L. Rev. 463, 486 (2001) (concluding that quick, low-stake examinations "encourage students to keep up with work and provide them with frequent feedback on their progress.")

29. But see Miller, supra n. 22, at 233 (admitting that "this reduction in grading time does come at the expense of additional preparation time. Good multiple-choice questions don't drop out of the sky: they can be devilishly difficult to construct and fine tune.")

30. Sergienko, supra n. 28, at 486.

31. See Gerdy, supra n. 11, at 67. "After all, when was the last time an attorney did research that had been 'sanitized' by a law librarian in advance to ensure that the desired resources and results were available?" Id. See also Callister, supra n. 8, at 27.

The neat order presented by the casebook method is illusory, a pedagogical nicety but an oversimplification of the world they will face in practicing law. To prepare for independence and to be weaned from their sterile law school environment of neatly tied case studies, students will need to learn to build their own paradigms. No subject offers a better opportunity to practice making order out of chaos than legal research.

Id.

32. See Janto \& Harrison-Cox, supra n. 13, at 290-91.

33. Id.

34. See Gerdy, supra n. 11, at 72 .

35. Id.

36. See id. at 67 (noting the distinction between well-defined and ill-defined problems).

37. See Fitzgerald, supra n. 3, at 265-266.

38. See David J. Boud \& Allen Tyree, Self and Peer Assessment in Professional Education: A Preliminary Study in Law, 15 J. Socy. Pub. Teachers L. 65, 65 (stating that lawyers' work is rarely judged formally, except when "something goes terribly wrong ... The lack of effective external assessment directing his day-to-day work means that his own ability to define goals and to self-assess his progress toward those goals must be better than those of most non-professionals.")

39. See Sergienko, supra n. 28, at 479 (2001) (noting that commentators believe "self reflection is a critical component of successful professional work.")

40. $C f$. Gerdy, supra n. 11, at 78 (noting that first-year students are eager for feedback of the type that they get in none of their other first-year courses.)

41. Brian Huddleston, Trial by Fire ... Creating a Practical Application Research Exam, 7 Persps. Teaching Leg. Research \& Writing 99, 99 (1999). Available at http://west.thomson.com/pdf/perspec/ trl0899.pdf. The response might be that, unlike concert pianists who are trained to perform before audiences, legal research is generally a solitary endeavor. There is little precedent for having a person standing over your shoulder watching you work. 
42. Professors tell students that they will not be penalized for wrong turns, but it defies logic to imagine that all of them take that advice to heart. In a similar situation, I would be tempted to clean up my work.

43. Of course, this does not take into account the time necessary to develop the research problems in the first place. Matthew Cordon suggests delegating the task to students. "The difficulty with developing a practical problem has been resolved to a degree by requiring students to draft research problems of their own creation." Cordon, supra n. 24, at 34.

44. Gerdy, supra n. 11, at 80.

45. Id. Gerdy's article includes numerous interesting ideas. Another is the "minute paper," through which students identifying the points they found most confusing in her lectures.

At the end of a class period, students are told to write for a minute or two on this question: "If you had to explain the most important concepts you learned today to a class member who was absent-and you are her only source of information-what would you tell her?" The papers, which are submitted anonymously, allow the teacher to assess how much the students have learned and to identify any misunderstandings or common questions.

Id. at 82

46. See Callister, supra n. 8, at 33 (arguing that the "fundamental use" of the Socratic method is "to force an examination of one's own view of the world, including the mental frameworks one develops for understanding and solving problems.")

47. As an adjunct at Fordham, I taught ALR in a smart computer lab. A control panel allowed me to select any computer in the room and broadcast that student's image through the projector. As a result, if someone had a problem-say, a process was not working correctly-we could all look at his or her work to discover what had gone wrong.

48. http://www.adobe.com/products/captivate.

49. http://www.techsmith.com/camtasia.asp.

50. http://camstudio.org. MediaNotes is another potentially useful tool. http://w.cali.org/medianotes. Distributed by Computer-Assisted Legal Instruction, MediaNotes allows teachers to annotate videos (created by Camtasia, CamStudio, or another program). Teachers can use it to point out specific points in the video where students made mistakes or could have followed a more straightforward approach.

51. The potential benefit of time saving for the professor is overwhelmed by the controversy it would cause-students in legal education want their professors to grade them, not other students. See Shirley Rawson \& Alan L. Tyree, Self and Peer Assessment in Legal Education, 1 Leg. Educ. Rev. 135, 140 (finding "great student hostility to the inclusion of self and peer assessment marks as part of the formal assessment process."); Sergienko, supra n. 28, at 485.

52. See Sergienko, supra n. 28, at 485 ("The work on incompetence in assessment ... raises questions about the ability of students to grade exam answers that do not conform well to a model answer.")

53. Ngar-Fun Liu \& David Carless, Peer Feedback: The Learning Element of Peer Assessment, 11 Teaching Higher Educ. 279, 280 (2006).

54. See Boud \& Tyree, supra n. 38, at 67

55. Liu \& Carless, supra n. 53, at 280.

56. See Boud \& Tyree, supra n. 38, at 65; Rawson \& Tyree, supra n. 51, at 136.

57. See Liu \& Carless supra n. 53 , at 281.

58. In 2000, more than two-thirds (sixty-nine percent) of all ALR classes featured pathfinder assignments. See Hemmens, supra n. 2, at 234. Some have used pathfinders as the principle component of students' final grades. See e.g. Peter C. Schanck, Mandatory Advanced Legal Research: A Viable Program for Law Schools, 92 L. Lib. J. 295, 298 (2000).

59. Cordon, supra n. 24, at 34. See also Wren \& Wren, supra n. 18, at 487 (identifying pathfinder projects as "training in legal reference, not legal research.")

60. Berring \& Vanden Heuvel, supra n. 17, at 446.

61. Id at 445 .

62. Easy to grade, though quite hard to write. See Miller, supra n. 22, at 233.

63. Staheli, supra n. 24, at 201.

64. See e.g. Fitzgerald, supra n. 3, at 267 (complaining that quizzes "test students' ability to find a source but do not assess whether a student knows when to find a source.”) 
65. Judith Rosenbaum, Why I Don't Give A Research Exam, 11 Persps. Teaching Leg. Research \& Writing 1, 5 (2002). Available at http://west.thomson.com/pdf/perspec/Fall\&202002/Fall021.pdf

66. Miller, supra n. 22, at 219.

67. See generally Huddleston, supra n. 41. Huddleston describes the process of administering a practical examination. It was not designed to test "their ability to perform broad, open-ended research that integrated multiple resources to provide a full answer to a complex legal question." Id. at 100. Rather, it sought to assess whether students could "correctly use specific legal bibliographic resources to find material based on given criteria." Id. at 101.

68. Stuckey, supra n. 7, at 133.

69. See Carnegie Report, supra n. 6, at 173 (noting that "[i]n law schools, the means of assessing the skills of practice mirror the wide array of pedagogical practices represented in lawyering and clinical courses. This diversity of assessment procedures can be seen as a strength, as reliance on a single format ... would be both impractical and ill-advised.")

70. Gerdy, supra n. 11, at 75.

71. See infra $n$. 49-50, and accompanying text.

72. Students may also enjoy the variety. And because different students will excel at different types of tasks, using a variety of approaches is equitable. See Gerdy, supra n. 11, at 75. 